\title{
HER2 Inhibitor
}

National Cancer Institute

\section{Source}

National Cancer Institute. HER2 Inhibitor. NCI Thesaurus. Code C159156.

Any agent that inhibits the human epidermal growth factor receptor 2 (HER2; HER-2;

ERBB2). 